acid is formed in the leucocytes present in the circula. tion. This lack of formation of labelled nucleic acid can scarcely be a consequence of the effect of X-rays on the turnover rate, because a dose of $2,000 \mathrm{r}$. diminishes, but does not entirely stop, the renewal of desoxyribosenucleic acid in all types of tissue investigated $^{5}$; it must be interpreted as a lack of formation of new white corpuscles. The turnover of desoxyribosenucleic acid present in the white corpuscles is thus negligible.

I wish to express my most cordial thanks to Prof. N. Bohr for numerous facilities put at my disposal, and to Prof. G. Hevesy for his kind interest and many helpful suggestions throughout the work.

Institute for Theoretical Physics, J. OTTESEN

University, Copenhagen.

'Hevesy, G., and Ottesen, J., Nature, 15B, 534 (1945).

2 Shemin, D., and Rittenberg, D., J. Biol. Chem., 168, 627 (1946).

- Butler, A. M., and Cushman, M., J. Clin. Jnvest., 19, 459 (1940).

4 Schmidt, G., and Thannhauser, S. J., J. Biol. Chem., 161, 83 (1945).

' Hevesy, G., Rev. Mod. Phys., 17, 102 (1945).

\section{Introduction of Radioactive Tracers into Antisera}

Ir has been found possible to introduce radioiodine into the globulin molecule of an antiserum without seriously impairing the agglutinating power of the serum.

The globulin fraction of a Proteus vulgaris rabbit antiserum was prepared by two successive precipitations with a 22 per cent concentration of sodium sulphate, and dissolved in $M / 15$ phosphate buffer of $p H$ 7. It was then treated with an aqueous iodine solution $(0.1 \mathrm{mgm} / \mathrm{ml}$.) containing also some 8-day radioiodine. Reaction is complete in a few minutes, approximately 20 per cent of the iodine being sub. stituted into the globulin. The remainder, now present as iodide, was removed by dialysis.

A solution containing $5 \mathrm{mgm}$. of the iodinated antiserum globulin in $70 \mathrm{ml}$. of $p H \quad 7$ phosphate buffer was mixed with $5 \mathrm{ml}$. of normal serum and sufficient Proteus suspension to remove all the agglutinins. After standing for one hour at $56^{\circ} \mathrm{C}$., the agglutinated bacteria were filtered out, washed, and their radioactivity determined. The accompanying table is typical of the results obtained.

\begin{tabular}{|c|c|}
\hline $\begin{array}{c}\text { Iodine atoms }(n) \text { per antiserum } \\
\text { globulin molecule (mean), assuming } \\
\text { mol. wt. globulin 156,000 }\end{array}$ & $\begin{array}{c}\text { Percentage of total } \\
\text { activity precipitated }\end{array}$ \\
\hline $1 \cdot 0$ & $8 \cdot 1$ \\
$2 \cdot 3$ & $8 \cdot 1$ \\
$3 \cdot 1$ & $9 \cdot 3$ \\
$7 \cdot 7$ & $5 \cdot 7$ \\
\hline
\end{tabular}

A control experiment with normal rabbit globulin gave only about one per cent of precipitable activity, which may have been due to naturally occurring agglutinins in the serum.

With increase of the iodine content above 10 atoms per molecule, the agglutinating titre and percentage of precipitable activity of the globulin showed a marked decrease. The iodine probably becomes substituted into the tyrosine residues, of which there are about 58 per molecule.

If the number of iodine atoms, $n$, as defined in the above table is small compared with 58, the prob- ability of a globulin molecule containing $m$ iodine atoms will be :

$$
\frac{n^{m}}{m !} \cdot \exp -n
$$

Consequently, for $n=1,36 \cdot 8$ per cent of the globulin molecules will contain no iodine; but for $n=7 \cdot 7$, only 0.05 per cent will contain no iodine. Since, however, over this range of $n$ the agglutinating titre showed little alteration, it follows that slightly iodinated antiserum globulin has substantially the same agglutinating properties as the untreated antiserum globulin.

It should be possible to use this technique for the standardization of a considerable variety of antisera.

I wish to thank Drs. R. F. Menzies and H. Bensted, who prepared the antisera. Acknowledgment is made to the Director, Atomic Energy Research Establishment, for permission to publish these results.

\section{F. D. S. Butement}

Atomic Energy Research Establishment, Harwell, Didcot, Berks,

June 1.

\section{Succinic Acid in the Blood of the Larva of Gastrophilus intestinalis}

DURING the course of biochemical investigations on the parasitic larvæ of the fly Gastrophilus intestinalis, advantage was taken of the ease with which the hæmoglobin-containing 'tracheal organ' cells' and the hæmolymph which surrounds them could be obtained in order to study the interrelationship between the two in vitro. For this purpose an investigation of the respiratory metabolism of the tracheal organ was undertaken, employing standard manometric methods.

The oxygen uptake of tracheal cells in either phosphate buffer or a specially prepared 'Gastrophilus Ringer' solution was small; but it was increased up to nine times in presence of the insect's own hæmolymph. Analyses of fructose, glucose, lactate, pyruvate, citrate and succinate having been made on the blood ${ }^{2,3}$, the effect of these substances, and of fumarate and butyrate, on the oxygen consumption of the tracheal cells suspended in phosphate buffer was determined. Only with succinate was there an increase in oxygen uptake comparable with that found when the hæmolymph was the suspension medium. Evidence that the factor present in the hæmolymph responsible for this increase is indeed succinate was obtained as follows.

Preliminary experiments showed that the active material was dialysable and could be extracted by ether at an acid $p H$. Accordingly, the blood from some 1,200 third-instar Gastrophilus larvæ was dialysed against three changes of distilled water. The combined external fluid was acidified to $p H \mathbf{~ 2}$, reduced in bulk by evaporation to 50 c.c., and continuously extracted with ether for ten hours. At this stage the aqueous phase was devoid of activity when tested with tracheal organ cells. The ether extract was then itself extracted three times with equal volumes of water, and the combined aqueous extract washed with a quarter of its volume of ether to remove easily ether-soluble substances. The aqueous solution was now evaporated to dryness, the 